\title{
Municipal Solid Waste Management and Waste to Energy in Karachi Pakistan ${ }^{\dagger}$
}

\author{
Aftab Ahmed 1,*, Arshad Hussain ${ }^{1}$, Shehdev Thahrani ${ }^{1}$, Sultan Ahmed ${ }^{2}$, Abdul Qadeer Khoso ${ }^{1}$ \\ and Bilal Soomro ${ }^{1}$ \\ 1 Department Mechanical Engineering, INDUS University, Karachi 75300, Pakistan; \\ arshad15me04@gmail.com (A.H.); shehdev@indus.edu.pk (S.T.); aqkhoso47@gmail.com (A.Q.K.); \\ bilal12mech@gmail.com (B.S.) \\ 2 Department Mathematics, Gdc College, Gambat 66070, Pakistan; sultaniccg@gmail.com \\ * Correspondence: aftabkhuhro12@gmail.com \\ + Presented at the 1st International Conference on Energy, Power and Environment, Gujrat, Pakistan, \\ 11-12 November 2021.
}

Citation: Ahmed, A.; Hussain, A.;

Thahrani, S.; Ahmed, S.; Khoso, A.Q.; Soomro, B. Municipal Solid Waste Management and Waste to Energy in Karachi Pakistan. Eng. Proc. 2021, 12,

19. https://doi.org/10.3390/ engproc2021012019

Academic Editor: M. Salman Haide

Published: 22 December 2021

Publisher's Note: MDPI stays neutral with regard to jurisdictional claims in published maps and institutional affiliations.

Copyright: (C) 2021 by the authors. Licensee MDPI, Basel, Switzerland. This article is an open access article distributed under the terms and conditions of the Creative Commons Attribution (CC BY) license (https:// creativecommons.org/licenses/by/ $4.0 /)$.

\begin{abstract}
The environmental protection agency shows that the solid waste management of Karachi city lies in the underdeveloped category. Organics, paper, plastics, bread, metals, bones, textile and many other components are key in this area. The current methods for disposing of solid waste in cities, land-filling and other schemes are compared. Energy crises and solid waste at this large scale has forced cities to the edges of collapsing. Still, it is feasible to convert this huge problem into a profitable business. With the exception of dumping or burning, waste can be used to produce energy. Through bio-chemical and thermo-chemical processes, almost $0.01 \%$ of the total energy demand can be reproduced from the waste mentioned above. There is a need to promote the production of energy from solid waste and the utilization of different wastes in a useful manner. Instead of using ineffective waste management schemes, proper waste management schemes can solve both problems at the same time. A huge amount of revenue can be generated from Karachi solid waste, but all this depends upon awareness and suitable technology. The focus of this paper is to emphasize the importance of recycling and energy. The choice of proper methods for treatment, fermentation, anaerobic digestion and the reasons for properly operating all solid waste management bodies are discussed in detail in this study. The Decision support System tool and its importance is also discussed in terms of the field of solid waste choice makers.
\end{abstract}

Keywords: solid waste; underdeveloped; organics; paper; plastics; dumping

\section{Introduction}

Karachi city has a population of around 22 million with seven districts and six cantonment boards. The city's waste is mainly collected by two institutions, one being the Sindh solid waste management board (SSWMB) and the other being the district municipal committee (DMC). Both of these have hired private contractors to collect the solid waste of city. The network works in the following way: waste is collected through front end collection points and stored at a garbage transport facility before being dumped into two main landfill areas. Karachi has two main landfills; one is Jam Chakro, and the other is Gondpas. There are no recycling mechanics for the city's waste [1]. All the developed cities of the world have a recycling stage for solid waste management. Without recycling, tackling such a huge city waste becomes almost impossible. The landfill sites are the only option available at present for managing Karachi city's solid waste, which is a dilemma itself. There are not any steps taken from academia or the industry to address the challenges related to the solid waste of this huge city [2]. This scheme or method is not recommended and even discouraged by environmentalists because it puts more stress on the environment and causes greenhouse gas emissions. The organic waste is the highest among all categories, 
and this waste can be converted into fertilizer and energy sources [3]. The Karachi Sabzi mandi, fresh juice shops, sugar can juice corners and other related sites produce a huge amount of organic waste comprising almost more than $20 \%$ of all the waste generated by the city. There is an immediate need to address this challenge of the city on a priority basis, and academia and the industry can both play their part. However, unfortunately both sides have been silent on this for decades [4]. The working network diagram is shown in Figure 1 below to understand the importance of recycling.

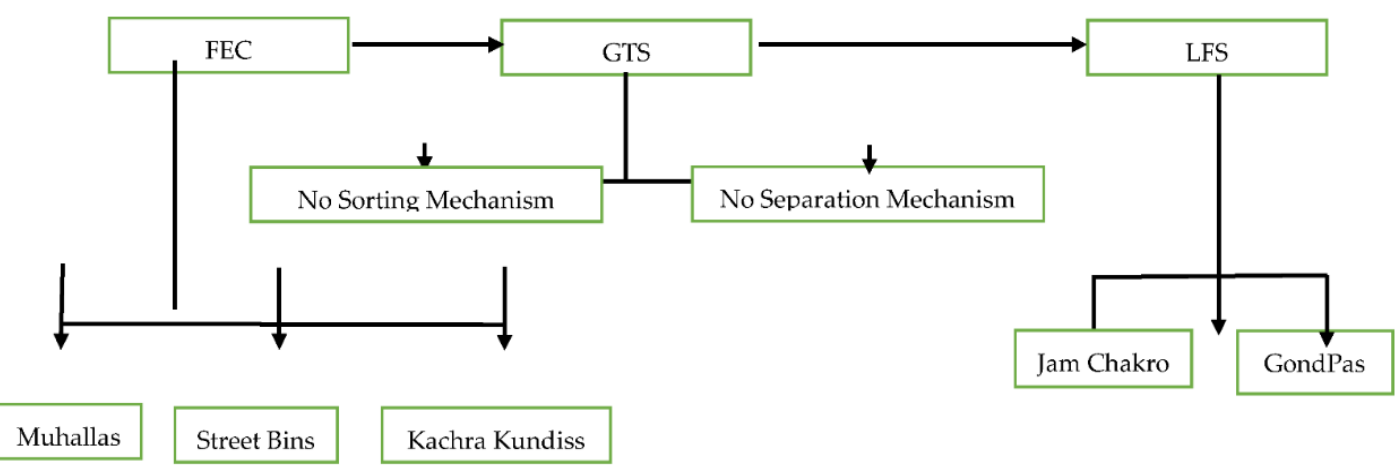

Figure 1. The network of solid waste for Karachi city.

Different types of authorized surveys should be conducted, from which solid waste management engineers can draw better conclusions instead of wondering around and providing no sustainable solution [5]. The focus should be on household urban and suburban areas, commercial sectors, including the textile, cement and construction industry in particular, vegetable markets and Sabzi mandi's; all these sectors should be thoroughly investigated. A huge amount of money goes into managing solid waste municipals, and this money can be used to produce a viable and sustainable solution for solid waste instead of utilizing the landfill. Furthermore, these landfills are also shorting out because most of them are already filled up to their maximum capacity and only few are left in which to dump the city's solid waste [4].

Household waste management schemes should be applied; inspired from other successful examples, advanced waste collection techniques should be modeled and practiced based on transportation needs [5]. The expected waste generated within the city can be calculated through the following equation on the basis of the population and generation rate of solid waste [5]:

$$
Q_{W(C T)}=\left(\left(P_{t} \times G R W \times 365\right) /(1000)\right)+\left(Q s_{a v}-Q s_{g s y}\right)
$$

Here, $Q_{W(C T)}$ represents the quantity of solid waste of a specific year, and $P_{t}$ represents the expected population of the city. The important factor here is GRW, which assumes the generation rate of solid waste per $\mathrm{kg} /$ capita of the city. GRW can be calculated through different methods, which will be described below. $Q s_{a v}$ And $Q s_{g s y}$ show the average quantity of waste generated per selected year. The following equation is used to calculate the expected population of the city with the safest error margin:

$$
P_{t}=P_{0}(1+r)^{n}
$$

$P_{0}$ represents the year of a given population, and $P_{t}$ shows the expected population of the city. The $n$ represents the total number $f$ of years, and $r$ represents the annual growth rate of the population of the particular city under study. Finally, the generation rate can be calculated through the following equation:

$$
G R W=Q_{W} /(P)
$$


Here, $Q_{W}$ represents the quantiity of solid waste per $\mathrm{kg}$, and $P$ shows the population of the city for one year. In this way, the generation rate of solid waste and expected population can be calculated. Once these parameters are calculated, the total solid waste generated by the city can be calculated easily [3]. Once calculations are done researchers try to estimate individual waste amount of different products such as given in Table 1 to deduce amount of recyclable waste.

Table 1. Waste generation and imports in Karachi, Pakistan.

\begin{tabular}{ccc}
\hline Agriculture, forestry (a) & 1905 & 2004 \\
Mining (b) & 267 & 606 \\
Manufacturing & 9549 & 9593 \\
Electricity, gas, water services & 902 & 724 \\
Waste management services (c) & 34 & 27 \\
Construction & 16,055 & 14,491 \\
All other industries (d) & 11,181 & 9948 \\
Industry total & 39,893 & 37,393 \\
Public administration & 847 & 690 \\
Households & 12,459 & 14,269 \\
Imports & 554 & 685 \\
Total supply of waste & 53,753 & 53,036 \\
\hline
\end{tabular}

Not having proper equipment and technology adds more problems where people's attitude towards waste is already not encouraging [5].

\section{Energy from Solid Waste}

For decades, Karachi city has faced several energy crises, which has finally come to an end. The city produces almost 12,000 to 15,000 tons of waste daily, and this huge amount of waste can be converted into energy. It was estimated through different studies that almost $100 \mathrm{~m}^{3}$ /ton could be produced from the organic waste of Karachi. Measuring the ph. value and analyzing the importance of the $\mathrm{PH}$ value is critical in producing biogas or methane from organic waste.

\section{Solid Wastes and Their Key Components}

Determining the key components of solid waste is critical to produce any sort of energy from it. Avoidable food includes cooked food, fresh fruits, vegetables, pasta, potatoes, etc. Avoidable animal extracted food waste includes eggs, meat and fish waste, which are also key components in this sector. Along with this waste, hazardous wastes include contaminated soils; asbestos reactive chemicals; paints, resins, inks and organic sludges; organic solvents, pesticides, oils, putrescible/organic waste; organic chemicals; other soil/sludge's including contaminated bio-solids, clinical and pharmaceutical wastes; tires; acids; alkalis; and inorganic chemicals [6]. Table 1 provides us total waste data from where recyclable waste amount has been mentioned in Table 2.

Table 2. Percentage of waste items in Karachi city.

\begin{tabular}{cc}
\hline Recyclable Waste & Non-Recyclable Waste \\
\hline Newspapers & Garbage \\
Mixed Paper & Food waste \\
Glossy Magazines and Ads & Food-tainted items \\
Cardboard & Ceramics and kitchenware \\
Paperboard & Windows and mirrors \\
Plastic Drink Bottles & Plastic wrap \\
Plastic Product Bottles & Peanut packaging and bubble wrap \\
Aluminum Cans & Wax boxes \\
Tissue boxes & Crystal \\
Shoeboxes & Tissue paper \\
Books & Light bulbs \\
Milk jugs & Foam materials
\end{tabular}




\section{Conclusions and Solutions}

Solid waste management is a critical challenge for every city around the globe. However, the Karachi city situation is unique and complicated when compared to any other city. The city was never constructed with any plan, and this has never been properly focused on during the last few decades. The sewage systems are also damaged, which also contributes to more solid waste, and solid waste leads to problems in the sewage systems. The academia sector can play a vital role in encouraging people to engage in the proper wasting of items, and awareness about solid waste is crucial. The industry sector should also play a role by providing funding to academia. The government should invest in recycling waste and producing biogas and methane from the organic waste of the city. This is only possible with academia's and the industry's cooperation. It has been estimated that a huge amount of methane can be produced from the solid waste of Karachi.

Conflicts of Interest: The authors declare no conflict of interest.

\section{References}

1. Korai, M.S.; Mahar, R.B.; Uqaili, M.A. The feasibility of municipal solid waste for energy generation and its existing management practices in Pakistan. Renew. Sustain. Energy Rev. 2017, 72, 338-353. [CrossRef]

2. Sohoo, I.; Ritzkowski, M.; Heerenklage, J.; Kuchta, K. Biochemical methane potential assessment of municipal solid waste generated in Asian cities: A case study of Karachi, Pakistan. Renew. Sustain. Energy Rev. 2021, 135, 110175. [CrossRef]

3. Khan, S.; Alvarez, L.C.M.; Wei, Y. Sustainable management of municipal solid waste under changing climate: A case study of Karachi, Pakistan. Asian J. Environ. Biotechnol. 2018, 2, 23-32.

4. Siddiqi, M.M.; Naseer, M.N.; Abdul Wahab, Y.; Hamizi, N.A.; Badruddin, I.A.; Chowdhury, Z.Z.; Akbarzadeh, O.; Johan, M.R.; Khan, T.M.; Kamangar, S. Evaluation of municipal solid wastes based energy potential in urban Pakistan. Processes 2019, 7, 848. [CrossRef]

5. Korai, M.S.; Mahar, R.B.; Uqaili, M.A. Optimization of waste to energy routes through biochemical and thermochemical treatment options of municipal solid waste in Hyderabad, Pakistan. Energy Convers. Manag. 2016, 124, 333-343. [CrossRef]

6. Umar, U.A.; Shafiq, N.; Ahmad, F.A. A case study on the effective implementation of the reuse and recycling of construction \& demolition waste management practices in Malaysia. Ain Shams Eng. J. 2021, 12, 283-291. 